\title{
UPAYA PENINGKATAN KUALITAS PELAYANAN JALAN TOL SEMARANG-BAWEN DENGAN INTEGRASI METODE IMPORTANCE PERFORMANCE GAPANALYSIS, LEAN, DAN SIX SIGMA
}

\author{
Diana Puspita Sari*, Ariani Putri Winanda, Arfan Bakhtiar, Dyah Ika, Yusuf Widharto
}

\author{
Program Studi Teknik Industri, Fakultas Teknik, Universitas Diponegoro \\ Jl. Prof. Soedharto, SH, Kampus Undip Tembalang, Semarang, Indonesia 50275
}

(Received: September 19, 2016/ Accepted: July 17, 2017)

\begin{abstract}
Abstrak
PT Trans Marga Jateng (TMJ) adalah sebuah perusahaan yang bergerak pada bidang jasa, yaitu mengelola jalan tol Semarang-Bawen. Berdasarkan survey pendahuluan yang dilakukan oleh PT TMJ menunjukkan bahwa kualitas pelayanan PT TMJ masih dianggap kurang memuaskan, sehingga perlu dilakukan penelitian mengenai peningkatan kualitas pelayanan. Kualitas pelayanan dapat diukur dari dua perspektif, yaitu perspektif internal dan perspektif eksternal. Perspektif eksternal dapat diukur dengan metode Importance Performance Gap Analysis (IPGA), sedangkan perspektif internal dapat diukur dengan metode Lean dan Six Sigma. Sehingga, penelitian ini menggunakan integrasi metode IPGA, Lean, dan Six Sigma dalam upaya meningkatkan kualitas pelayanan PT TMJ. Berdasarkan hasil penelitian, atribut kualitas pelayanan yang dianggap paling berpengaruh adalah penerangan jalan, kemulusan permukaan jalan, keselamatan mengemudi, dan penanganan kecelakaan. Usulan perbaikan yang diberikan untuk masing-masing atribut adalah penambahan lampu penerangan di titik-titik rawan kecelakaan, pemberian lapisan aspal pada bagian-bagian jalan yang bergelombang, memberikan perhatian khusus terhadap pelaksanaan indikator-indikator keselamatan mengemudi, dan perbaikan value stream pada penanganan kecelakaan. Value stream mapping hasil perbaikan menghasilkan waktu total lead time sebesar 150 menit dan persentase aktivitas value added sebesar 72,6\%.
\end{abstract}

Kata kunci : Kualitas pelayanan, IPGA, Lean, Six Sigma

\begin{abstract}
PT Trans Marga Jateng (TMJ) is a company engaged in service sector, which is managing SemarangBawen toll road. The result of preliminary surveyconducted by PT TMJ showed that service quality of PT TMJ is still unsatisfactory, so it is necessary to do research on improving service quality. Service quality can be measured from two perspectives, i.e., internal perspective and external perspective. The external perspective can be measured with Importance Performance Gap Analysis (IPGA) method, while the internal perspective can be measured with Lean and Six Sigma method. Thus, this study will use the integration method of IPGA, lean, and six sigma in effort to improve service quality of PT TMJ. Based on the research result, service quality attributes considered the most influential is road lighting, road surface smoothness, driving safety, and accident handling. Suggested improvements for each attribute are road lighting installation at vulnerable points of accidents, asphalt layer installation on bumpy roads, paying particular attention to the implementation of safety driving indicator, and improving value stream of accident handling. Based on future state value stream mapping, total lead time is 150 minutes and value added activity percentage is $72,6 \%$.
\end{abstract}

Keywords : Service Quality, IPGA, Lean, Six Sigma

\footnotetext{
*) Penulis Korespondensi.

Email : diana_psptsr@yahoo.com
} 


\section{Pendahuluan}

Bertambahnya jumlah kendaraan ini menyebabkan permasalahan kemacetan, terlebih pada jam sibuk seperti berangkat kerja dan jam pulang kerja. Jalan arteri yang sebelumnya digunakan sebagai lalu lintas jarak jauh, telah bercampur fungsi, baik dengan jalan kolektor maupun jalan lokal. Hal tersebut mendorong permintaan akan pembangunan jalan arteri yang bertipe bebas hambatan. Namun, untuk mewujudkan jalan seperti ini dibutuhkan dana yang sangat besar, sementara dana Anggaran Pendapatan dan Belanja Negara sangat terbatas, sehingga pada tahun 1978 ditetapkan sistem tol pada jalan bebas hambatan pertama di Indonesia yaitu ruas JakartaCibinong sepanjang 27 kilometer.

Salah satu jalan tol yang beroperasi di Kota Semarang adalah jalan tol Semarang-Bawen. Jalan tol Semarang-Bawen ini baru beroperasi selama 5 tahun dan dikelola oleh PT Trans Marga Jateng (TMJ), yang merupakan anak perusahaan dari PT Jasa Marga (Persero) Tbk. Berdasarkan survey kepuasan pelanggan yang dilakukan di PT Trans Marga Jateng, masih terdapat beberapa pelayanan yang belum mencapai standar kepuasan. Beberapa pelayanan tersebut diantaranya adalah penanganan antrian saat membayar tol, kecepatan penanganan gangguan perjalanan oleh petugas patroli jalan tol, kecepatan penanganan gangguan perjalan oleh petugas derek, permukaan jalan tol, penerangan jalan tol, penghijauan di sepanjang jalan tol, layanan informasi jalan tol, layanan Polisi Jalan Raya (PJR), dan penanganan pelanggaran lalu lintas oleh PJR. Hal ini menunjukkan bahwa pelayanan yang diberikan PT Trans Marga Jateng masih dianggap belum memenuhi kepuasan pelanggan. Kepuasan pelanggan terbentuk dari pengalaman atas mengonsumsi jasa yang telah didapatkan. Tingkat kualitas pelayanan tidak dapat dinilai berdasarkan sudut pandang perusahaan, namun harus dinilai dari sudut pandangan pelanggan (Rangkuti, 2006).

Menurut Sachdev danVerma (2004), ada dua perspektif untuk mengukur kualitas layanan, yaitu perspektif internal dan perspektif eksternal. Perspektif eksternal dilakukan untuk memahami harapan konsumen, persepsi konsumen, dan kepuasan konsumen. Untuk mengukur perspektif eksternal dapat digunakan metode Importance Performance Gap Analysis (IPGA). IPGA merupakan pengembangan dari metode IPA yang selain mengukur kepentingan dan kinerja suatu pelayanan, juga memperhatikan gap dari tiap atribut kualitasnya. Sedangkan perspektif internal diidentifikasikan dengan bebas kesalahan (zero defect) dan melakukan dengan benar saat pertama kali (getting it right first time), serta menyesuaikan permintaan konsumen. Selain itu, proses jasa atau layanan yang tepat waktu juga mempengaruhi kepuasan konsumen. Maka, untuk mengukur perspektif internal dapat digunakan metode Lean Six Sigma. Dengan melakukan penelitian menggunakan integrasi metode IPGA, Lean, dan Six
Sigma ini, diharapkan kualitas pelayanan PT Trans Marga Jateng dapat meningkat dan kebutuhan akan kepuasan pelanggannya dapat dipenuhi. Lean merupakan suatu pendekatan sistematis untuk mengidentifikasi dan mengeliminasi pemborosan (waste) melalui serangkaian aktivitas perbaikan (Gaspersz, 2007). Tools yang digunakan adalah Value Stream Mapping (VSM), VSM merupakan alat untuk memetakan aliran proses yang membantu mengidentifikasi berbagai macam faktor seperti value added time, non value added time, waktu siklus, waktu set up, dan sebagainya (Venkataraman et al, 2014). Six Sigma adalah implementasi yang tepat, fokus, dan efektif dalam membuktikan prinsip dan teknik mengenai kualitas. Dengan menggabungkan elemenelemen dari hasil pemikiran berbagai ahli kualitas, Six Sigma bertujuan untuk menciptakan performansi bisnis tanpa kesalahan. Standar Six Sigma sebesar 3,4 permasalahan per satu juta kesempatan (DPMO) adalah sebuah tanggapan untuk meningkatkan ekspektasi customer dan bertambahnya kerumitan produk dan proses modern (Pyzdek, 2002).

Penelitian ini bertujuan mengidentifikasi atribut yang paling berpengaruh terhadap kualitas pelayanan. Setelah didapatkan atribut yang paling berpengaruh dalam kualitas layanan, maka selanjutnya adalah mengidentifikasi tipe-tipe waste yang terjadi pada proses layanan dengan menggunakan value stream mapping. Setelah didapatkan waste yang terjadi dalam proses layanan, maka selanjutnya adalah menentukan Critical To Quality (CTQ) dan melakukan perhitungan kapabilitas proses. Kemudian, faktor-faktor penyebab terjadinya waste diidentifikasi dengan menggunakan Root Cause Analysis. Tahap terakhir adalah memberikan usulan perbaikan berdasarkan hasil identifikasi faktor penyebab waste dengan RCA yang memerlukan prioritas perbaikan, menganalisis jenis waste yang terjadi pada atribut yang bermasalah dan mengukur kapabilitas proses, serta yang terakhir adalah memberikan usulan perbaikan.

\section{Bahan dan Metode}

Tahapan penelitian diawali dengan studi pendahuluan, identifikasi dan perumusan masalah, perancanangan mekanisme penelitian, penyusunan dan penyebaran kuesioner, uji validitas dan reliabilitas, pengolahan data dengan IPGA, pengumpulan data Lean, dan pengolahan data dan analisa dengan IPGA, Lean, Six Sigma.

\section{Penentuan Responden dan Sampel}

Responden pada penelitian adalah pengguna jalan tol Semarang-Bawen. Metode pengambilan sampel yang digunakan yaitu convenience sampling, yaitu sampel diambil berdasarkan ketersediaan dan kemudahan untuk mendapatkannya. Pengambilan sampel berdasarkan rumusan Slovin dapat dilakukan bila jumlah populasinya sudah diketahui sehingga dapat dengan pasti ditentukan jumlah sampel yang terlibat di dalamnya (Umar, 2002). Diketahui bahwa 
pada tahun 2015, terdapat sebanyak \pm 51.889 kendaraan perharinya yang melewati jalan tol Semarang-Bawen, sehingga jumlah minimal sampelnya sebesar:

$$
\mathrm{n}=\frac{51.899}{1+51.899 .1036^{2}}=99,8077 \approx 100 \text { responden }
$$

\section{Penyusunan Kuesioner}

Penelitian ini menggunakan kuesioner yang ditujukan kepada pengguna jalan tol SemarangBawen. Kuesioner dibagi menjadi tiga bagian. Bagian pertama adalah identitas responden yang digunakan untuk mengumpulkan data karakteristik responden. Bagian kedua adalah kuesioner yang berisi pertanyaan tingkat kepentingan atribut bagi responden. Bagian ketiga adalah kuesioner yang berisi pertanyaan tingkat kepuasan atribut bagi responden. Skala yang digunakan adalah skala likert dari 1-5, dimana 1 bernilai sangat tidak puas dan 5 bernilai sangat puas. Variabel yang digunakan dalam penelitian ini didapatkan dari hasil studi literatur yang terkait dengan penelitian. Variabel penelitian yang digunakan adalah dimensi kualitas berdasarkan model TRSQ, yaitu information, accessibility, reliability, mobility, safetyandsecurity, dan responsiveness (Zuna, 2016). Variabel penelitian yang digunakan ditunjukkan pada tabel 1 .

\section{Pengolahan dan Analisa Data}

Pengolahan dan analisa data pada penelitian ini menggunakan sistem integrasi yang terdiri dari metode IPGA, Lean, dan Six Sigma. Setelah kuesioner disebar dan didapatkan hasilnya, hasil kuesioner tersebut diolah dengan menggunakan metode IPGA untuk mendapatkan menentukan atribut yang paling berpengaruh yang akan dijadikan sebagai objek amatan yang akan dicari akar penyebabnya serta perbaikannya. Setelah didapatkan atribut yang paling berpengaruh dalam kualitas layanan, maka selanjutnya adalah mengidentifikasi tipe-tipe waste yang terjadi pada proses layanan dengan menggunakan value stream mapping. Setelah didapatkan waste yang terjadi dalam proses layanan, maka selanjutnya adalah menentukan Critical To Quality (CTQ) dan melakukan perhitungan kapabilitas proses. Kemudian, faktor-faktor penyebab terjadinya waste diidentifikasi dengan menggunakan Root Cause Analysis. Tahap terakhir adalah memberikan usulan perbaikan berdasarkan hasil identifikasi faktor penyebab waste dengan RCA.
Tabel 1. Variabel Penelitian

\begin{tabular}{|c|c|c|}
\hline Dimensi & Notasi & Indikator \\
\hline \multirow{2}{*}{ Information } & A1 & $\begin{array}{lll}\text { Akurasi informasi } & \text { di } \\
\text { jalan tol } & & \end{array}$ \\
\hline & $\mathrm{A} 2$ & Rambu/papan Informasi \\
\hline \multirow{4}{*}{ Accessibility } & B1 & Gardu tol \\
\hline & $\mathrm{B} 2$ & Kinerja petugas gardu tol \\
\hline & B3 & $\begin{array}{l}\text { Keramahan petugas } \\
\text { gardu tol }\end{array}$ \\
\hline & B4 & $\begin{array}{l}\text { Kejujuran petugas gardu } \\
\text { tol }\end{array}$ \\
\hline \multirow{2}{*}{ Reliability } & $\mathrm{C} 1$ & $\begin{array}{l}\text { Kemulusan permukaan } \\
\text { jalan }\end{array}$ \\
\hline & $\mathrm{C} 2$ & Penerangan jalan \\
\hline Mobility & D1 & Tidak terdapat kemacetan \\
\hline \multirow{2}{*}{$\begin{array}{l}\text { Safety and } \\
\text { security }\end{array}$} & E1 & Keselamatan mengemudi \\
\hline & E2 & $\begin{array}{l}\text { Keamanan dari tindak } \\
\text { kejahatan }\end{array}$ \\
\hline \multirow{4}{*}{ Responsiveness } & $\mathrm{F} 1$ & Penanganan kecelakaan \\
\hline & $\mathrm{F} 2$ & $\begin{array}{l}\text { Perbaikan } \\
\text { jalan }\end{array}$ \\
\hline & F3 & Call center \\
\hline & $\mathrm{F} 4$ & $\begin{array}{l}\text { Kecepatan penanganan } \\
\text { petugas darurat }\end{array}$ \\
\hline
\end{tabular}

\section{Hasil dan Pembahasan \\ Perhitungan IPGA}

Untuk menentukan atribut yang paling berpengaruh pada pelayanan yang diberikan jalan tol Semarang-Bawen, dilakukan perhitungan dan pemetaan menggunakan metode IPGA atau importance performance gap analysis. Metode IPGA merupakan pengembangan dari metode IPA yang selain mengukur kepentingan dan kinerja suatu pelayanan, juga memperhatikan gap dari tiap atribut kualitasnya. Metode IPGA dikembangkan oleh Lin pada tahun 2009. Dari hasil pemetaan matriks IPGA, yang ditunjukkan oleh gambar 1, didapatkan bahwa terdapat 8 atribut yang berada pada kuadran II dan 7 atribut yang berada pada kuadran III. Kemudian, dilakukan perhitungan jarak untuk mengetahui prioritas dari tiap-tiap atribut. Dari hasil perhitungan IPGA pada tabel 2 diketahui bahwa terdapat 4 atribut yang memiliki jarak lebih dari 1. 


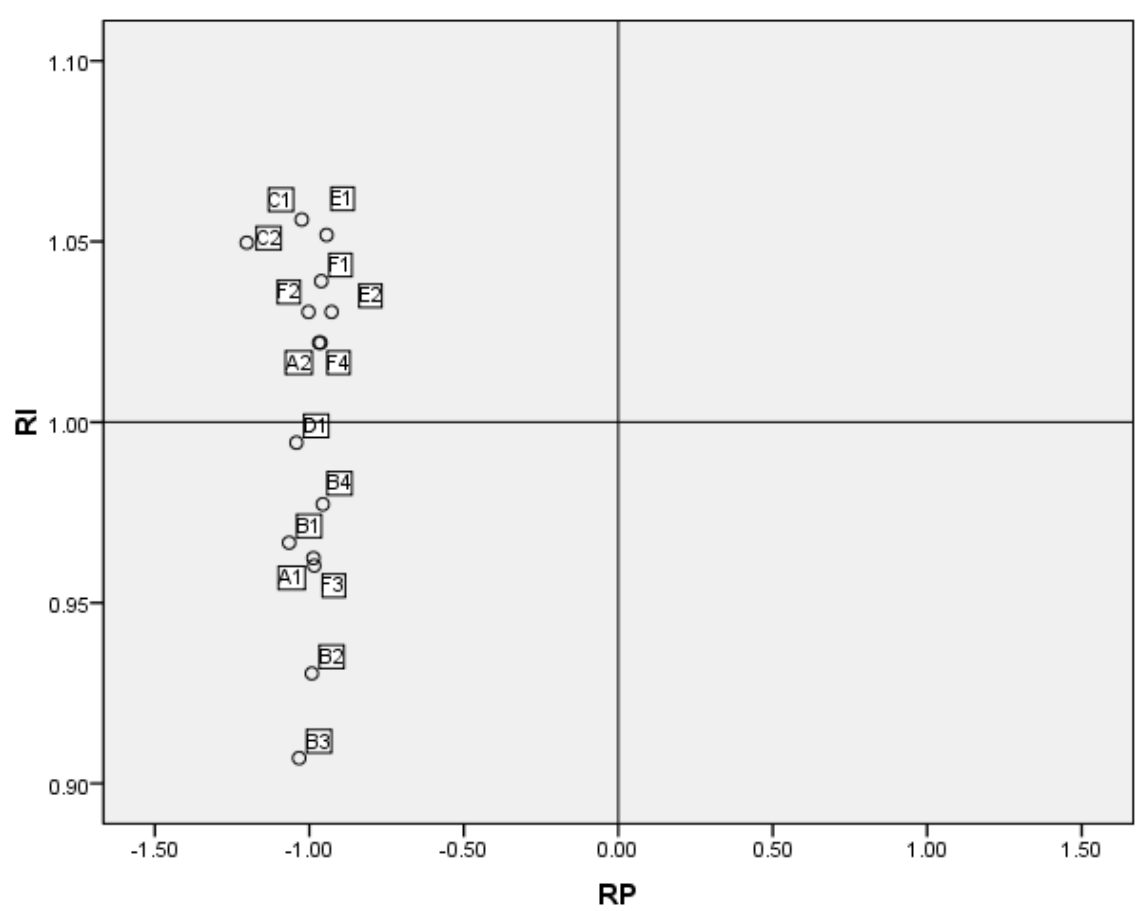

Gambar 1. Pemetaan Matriks IPGA

Tabel 2. Hasil Perhitungan IPGA

\begin{tabular}{cccccccc} 
Atribut & Importance & Performance & t-value & RI & RP & Kuadran & Distance \\
\hline A1 & 4,2243 & 3,5421 & $-7,5568$ & 0,9624 & $-0,9868$ & 3 & 1,0106 \\
\hline A2 & 4,4860 & 3,6262 & $-10,7203$ & 1,0220 & $-0,9639$ & 2 & 0,8924 \\
\hline B1 & 4,2430 & 3,2804 & $-9,8673$ & 0,9666 & $-1,0655$ & 3 & 1,0624 \\
\hline B2 & 4,0841 & 3,5234 & $-6,8188$ & 0,9304 & $-0,9920$ & 3 & 1,1943 \\
\hline B3 & 3,9813 & 3,3832 & $-6,1476$ & 0,9070 & $-1,0332$ & 3 & 1,3929 \\
\hline B4 & 4,2897 & 3,6542 & $-7,0038$ & 0,9773 & $-0,9565$ & 3 & 0,9303 \\
\hline C1 & 4,6355 & 3,4112 & $-13,6242$ & 1,0561 & $-1,0247$ & 2 & 1,3138 \\
\hline C2 & 4,6075 & 2,9065 & $-14,8088$ & 1,0497 & $-1,2026$ & 2 & 1,3361 \\
\hline D1 & 4,3645 & 3,3551 & $-9,1825$ & 0,9943 & $-1,0418$ & 3 & 0,9796 \\
\hline E1 & 4,6168 & 3,7009 & $-9,9450$ & 1,0518 & $-0,9444$ & 2 & 1,2127 \\
\hline E2 & 4,5234 & 3,7664 & $-8,1919$ & 1,0305 & $-0,9280$ & 2 & 0,9444 \\
\hline F1 & 4,5607 & 3,6355 & $-10,3159$ & 1,0390 & $-0,9614$ & 2 & 1,0601 \\
\hline F2 & 4,5234 & 3,4860 & $-12,0205$ & 1,0305 & $-1,0027$ & 2 & 0,9957 \\
\hline F3 & 4,2150 & 3,5514 & $-7,5919$ & 0,9603 & $-0,9842$ & 3 & 1,0178 \\
\hline F4 & 4,4860 & 3,6075 & $-8,6918$ & 1,0220 & $-0,9689$ & 2 & 0,8962 \\
\hline
\end{tabular}

\section{Penentuan Atribut Paling Berpengaruh}

Dari hasil perhitungan IPGA yang telah dilakukan pada tahap sebelumnya, dapat dilihat bahwa terdapat 4 atribut yang berada di kuadran II dan memiliki nilai distance di atas 1 yang diantaranya adalah penerangan jalan, kemulusan permukaan jalan, keselamatan mengemudi, dan penanganan kecelakaan. Pemberian usulan untuk atribut penerangan jalan, 
kemulusan permukaan jalan, dan keselamatan mengemudi dapat langsung diberikan dengan menggunakan wawancara dan studi literatur. Sedangkan untuk atribut penanganan kecelakaan memerlukan analisis lebih lanjut dengan metode lean six sigma untuk pemberian usulannya.

\section{Identifikasi Waste}

Setelah diketahui atribut yang paling berpengaruh pada jalan tol Semarang-Bawen, yaitu atribut penanganan kecelakaan, maka selanjutnya diintegrasikan dengan metode Lean, untuk mengidentifikasi waste yang terjadi pada proses pelayanan penanganan kecelakaan di jalan tol Semarang-Bawen. Pada value stream mapping current state penanganan kecelakaan, total waktu siklusnya sebesar 123 menit dengan lead time total sebesar 164 menit. Kemudian dilakukan pengidentifikasiaan waste di sepanjang value stream, yang menghasilkan 6 jenis waste, dan perhitungan pembobotan waste dapat dilihat pada tabel 3. Pada tabel 3, dapat dilihat bahwa waste yang memiliki prioritas tertinggi dan dianggap paling berpengaruh pada pelayanan penanganan kecelakaan adalah waste overprocessing.
Tabel 3. Hasil Pembobotan Waste

\begin{tabular}{|c|c|c|c|c|c|}
\hline No & Waste & $\begin{array}{c}\text { Bobot } \\
\text { (B) }\end{array}$ & $\begin{array}{l}\text { Frekuensi } \\
\text { (F) }\end{array}$ & $\mathbf{B x F}$ & $\begin{array}{c}\text { Priori } \\
\text { tas }\end{array}$ \\
\hline 1 & Overprocessing & 2,6 & 3,8 & 9,88 & 1 \\
\hline 2 & Motion & 3,2 & 3,0 & 9,60 & 2 \\
\hline 3 & Defect & 3,6 & 1,8 & 6,48 & 4 \\
\hline 4 & Waiting & 3,8 & 1,4 & 5,32 & 6 \\
\hline 5 & Overproduction & 1,8 & 3,0 & 5,40 & 5 \\
\hline 6 & Transportation & 3,0 & 2,6 & 7,80 & 3 \\
\hline
\end{tabular}

\section{Perhitungan Kapabilitas Proses}

Untuk menghitung kapabilitas proses, dilakukan terlebih dahulu identifikasi critical to quality (CTQ) dari waste yang paling berpengaruh. Diketahui bahwa terdapat 3 CTQ dari waste overprocessing. Kemudian, dilakukan perhitungan kapabilitas proses yang dapat dilihat pada tabel 4 .

Tabel 4. Perhitungan Kapabilitas Proses

\begin{tabular}{|c|c|c|c|}
\hline Langkah & Aktivitas & Persamaan & Hasil \\
\hline 1 & Proses layanan apa yang diamati? & & $\begin{array}{l}\text { Pelayanan Penanganan } \\
\text { Kecelakaan }\end{array}$ \\
\hline 2 & Berapa kali aktivitas terjadi? & & 141 \\
\hline 3 & Berapa kali waste terjadi? & & 282 \\
\hline 4 & Hitung tingkat keluhan & langkah 3/ langkah 2 & 2,0000000 \\
\hline 5 & $\begin{array}{l}\text { Tentukan banyaknya CTQ potensial } \\
\text { yang dapat mengakibatkan keluhan! }\end{array}$ & $\begin{array}{l}\text { Banyaknya } \\
\text { karakteristik CTQ }\end{array}$ & 3 \\
\hline 6 & $\begin{array}{l}\text { Hitung peluang tingkat keluhan per } \\
\text { karakteristik CTQ }\end{array}$ & langkah 4/ langkah 5 & 0,6666667 \\
\hline 7 & $\begin{array}{l}\text { Hitung kemungkinan keluhan per satu } \\
\text { juta kesempatan (DPMO) }\end{array}$ & langkah $6 \times 1.000 .000$ & 666666,667 \\
\hline 8 & Konversi DPMO ke dalam nilai sigma & & 1,07 \\
\hline 9 & Kesimpulan & & Kapabilitas Proses $1,07 \sigma$ \\
\hline
\end{tabular}

\section{Usulan Perbaikan}

Terdapat dua usulan perbaikan untuk peningkatan kualitas pelayanan jalan tol SemarangBawen. Usulan perbaikan pertama diberikan berdasarkan hasil analisis IPGA, dimana terdapat 4 atribut yang dianggap memiliki prioritas untuk diperbaiki terlebih dahulu. Usulan perbaikan kedua diberikan berdasarkan pengolahan data Lean, Six Sigma, dan hasil analisis dengan RCA untuk mencari akar penyebab dari waste overprocessing.
Usulan perbaikan berdasarkan analisis IPGA untuk kualitas pelayanan jalan tol Semarang-Bawen adalah perbaikan terhadap kemulusan permukaan jalan tol Semarang-Bawen ini dengan memberikan lapisan aspal di bagian-bagian jalan yang bergelombang, perlu dilakukan penambahan beberapa lampu penerangan di titik-titik yang dianggap rawan kecelakaan, dan untuk menjaga keselamatan mengemudi di jalan tol Semarang-Bawen perlu memperhatikan pelaksanaan 
indikator-indikator keselamatan mengemudi yang sudah diatur di dalam SPM.

Usulan perbaikan berdasarkan pengolahan data Lean Six Sigma untuk kualitas pelayanan jalan tol Semarang-Bawen adalah penyampaian informasi disampaikan langsung kepada seluruh petugas terkait tidak hanya secara khusus pada petugas PIK, pembuatan sistem perekapan yang terkomputerisasi dan terintegrasi antara data korban dan laporan harian PIK, dan pengeliminasian pemborosan yang menghasilkan value stream mapping future state yang memiliki total waktu siklus sebesar 109 menit dengan total lead time-nya sebesar 150 menit.

\section{Kesimpulan}

Berdasarkan hasil perhitungan dan pemetaan IPGA, terdapat 4 atribut pada kuadran II yang memiliki diatas 1, yang dianggap paling berpengaruh terhadap kualitas pelayanan, sehingga perlu diperbaiki terlebih dahulu. Dari keempat atribut tersebut, usulan perbaikan untuk atribut penanganan kecelakaan memerlukan analisis lebih lanjut menggunakan metode Lean Six Sigma. Pada proses penangan kecelakaan ditemukan 6 jenis waste yang terjadi, dan waste overprocessing memiliki bobot perbaikan yang paling tinggi, yaitu sebesar 9,88. Nilai kapabilitas proses yang dihitung berdasarkan CTQ dari waste overprocessing adalah sebesar 1,07 sigma. Setelah dilakukan pengeleminasian waste overprocessing, didapatkan total lead time pada VSM akhir sebesar 150 menit, dimana pada VSM awal sebesar 164 menit. Untuk hasil yang lebih baik, penelitian ini perlu dilakukan secara berkala dan terus-menerus, sehingga nilai sigma dari perusahaan dapat terukur dengan jelas perkembangannya, dan dapat menjadi pembelajaran untuk peningkatan kualitas pelayanan di masa depan.

\section{Ucapan Terima Kasih}

Penulis menyampaikan ucapan terima kasih kepada Program Studi Teknik Industri, Fakultas Teknik, Universitas Diponegoro yang telah memberikan dukungan dana "Hibah Penelitian Dasar" dalam pelaksanaan penelitian ini.

\section{Daftar Pustaka}

Cheng, Ching C., Tsai, Ming C., dan Lin, Shu P.. 2013. Developing strategies for improving the service quality of casual-dining restaurants: New insights from integrating IPGA and QFD analysis. Total Quality Management, 2015, Vol. 26, No.4, hal. 415-429.
Gaspersz, V. 2007. Lean Six Sigma for Manufacturing and Services Industries. Jakarta : PT Gramedia Pustaka Utama.

Lin, Shu P., Chan, Ya H., dan Tsai, Mung C.. 2009. A transformation function corresponding to IPA and gap analysis. Total Quality Management, Vol. 20, No.8, Agustus 2009, hal. 829-846

Panuti, S., Anggraeni, S. K., dan Bahauddin, A. 2013. Rancangan Perbaikan Kualitas Layanan Poliklinik Kulit dan Kelamin RSUD Cilegon dengan Pengintegrasian Metode Servqual, Lean, dan Six Sigma. Jurnal Teknik Industri, Vol.1, No.2, Juni 2013, hal. 169-173.

Pyzdek, T. 2002. The Six Sigma Hand Book. Jakarta : Salemba Empat.

Rangkuti, F. (2006). Measuring Customer Satisfaction: Teknik Mengukur dan Strategi Meningkatkan Kepuasan Pelanggan Plus Analisis Kasus PLN-JP. Jakarta: Gramedia Pustaka Utama.

Sachdev, S. B., dan Verma, H. V.. 2004. Relative Importance of Service Quality Dimentions: A Multisectoral Study. Journal of Service Research Vol. 4, No.1.

Sulistyowati, W., Supriyanto, H., dan Suef, M. 2008. Integrasi Metode Servqual, Lean, dan Six Sigma Implementasi: PT PLN (Persero) Distribusi Jawa Timur, APJ Surabaya Selatan - UPJ Ngagel. Prosiding Seminar Nasional Manajemen Teknlogi XII: Institut Teknologi Surabaya, hal. A-3-1 - A3-10.

Umar, H. 2002. Riset Pemasaran \& Perilaku Konsumen. Jakarta : Gramedia Pustaka Utama

Venkataraman, K., Ramnath, B.V., Kumar, V.M., dan Elanchezhian, C., 2014. Application of Value Stream Mapping for Reduction of Cycle Time in a Machining Process. Procedia Materials Science, 6 , pp. $1187-1196$

Zuna, Herry T., Hadiwardoyo, Sigit P., dan Rahadian, Hedy. 2016. Developing A Model Of Toll Road Service Quality Using An Artificial Neural Network Approach. International Journal of Technology (2016) No.4, hal. 562-570. 